\title{
Physical factors influencing active emergence of meiofauna from boreal intertidal sediment
}

\author{
Werner Armonies
}

Biologische Anstalt Helgoland (Litoralstation), D-2282 List, Federal Republic of Germany

\begin{abstract}
Some intertidal meiobenthic taxa actively emerge from the sediment and enter the water column. Laboratory experiments were conducted to test whether emigration is influenced by physical factors. Light exposure correlates negatively with the numbers of Copepoda, Plathelminthes and veliger-larvae swimming into the water column and the numbers of Ostracoda that are active on the sediment surface, perhaps reflecting a general means of predator avoidance. A temperature lower than seasonally occurring in the field strongly decreased emigration. Oxygen deficiency did not affect Ostracoda and veliger-larvae but caused additional plathelminth species to enter the water column. More copepods (copepodites) emerged from the sediment when oxygen content was increased by constant illumination. Interstitial salinity affected the numbers of Copepoda and Plathelminthes leaving the sediment. Highest swimming activity was recorded from interstitial salinities $>30 \%$. From sediment with ambient salinity, similar numbers of Copepoda entered water columns with 25 to $35 \%$ but significantly fewer individuals entered 20 and $40 \%$ water. Ostracod activity was only decreased at $40 \%$. Plathelminth swimming activity was negatively correlated with the salinity of overlying water. These results suggest a strong dependence of emigration rates on physical factors with taxa responding in differential ways. Generally, emigration into the water column may be (1) an integral part of meiobenthic life style, enhancing dispersal and, possibly, allowing for exploitation of food resources in the water column; or (2) a means of escape from dangerous factors in the sediment, either physical or biotic.
\end{abstract}

\section{INTRODUCTION}

While recent knowledge of meiobenthic occurrence in the water column was restricted to sublittoral, predominantly tropical to warm temperate shallow waters, Armonies (1988a) reported on active meiobenthic emergence into the water column in a boreal intertidal area. When water currents were experimentally excluded, up to $87 \%$ of Copepoda and $42 \%$ of Plathelminthes swam into the water column above sandy intertidal sediment during a single simulated nocturnal high tide. At the same time Ostracoda were active on the sediment surface and up to $67 \%$ of them left the experimentally submerged sediment. On the other hand, Nematoda, Oligochaeta, and Gastrotricha did not actively leave submerged sediment (Armonies 1988a).

Alldredge \& King (1980) proposed such short-term swimming activity of meiobenthos to be a means of dispersal over short distances. Other causes of active swimming might be endobenthic and epibenthic predator avoidance, disturbance (Reise 1985) or decreased food availability (Montagna et al. 1983). Finally, deterioration of physical factors might either cause emigration or change the pattern of routine emigrations performed for another purpose.

The physical factors most likely to affect migration include oxygen, salinity, temperature, and light. Oxygen availability may change on a small scale with differences in sediment composition and the amount of organic matter (Fenchel et al. 1967, Jansson 1967a, Revsbech et al. 1980), strongly influencing the vertical distribution patterns (e.g. Armonies \& Hellwig 1986). Precipitation, evaporation and freshwater runoff may cause salinity changes in the intertidal, although such changes are most pronounced in the supratidal belt (Jansson 1967b, Armonies 1987). Finally, temperature and light exposure will regularly change along the tidal gradient. Therefore, if physical harshness is a cause of meiobenthic emigration into the water column, oxygen deficiency should have a strong effect because shortterm swimming might lead the benthos into an area 
with better conditions nearby. Unfavourable salinity and temperature might indicate that the present position of an individual is too far up or down in the tidal gradient. Leaving the sediment and moving in the water column (either actively or by the help of currents; Armonies 1988b) may improve the physical environment without much energy expenditure.

Laboratory studies of oxygen, temperature, salinity and light exposure effects on the meiobenthic emergence pattern are the subject of this paper. It has already been shown that significant percentages of meiofaunal taxa may leave boreal intertidal sediment (Armonies 1988a). The aim of this paper is to test for variations in the emergence pattern of active swimmers caused by the above physical factors. In the sediment there are some truly benthic species which have never been found in the water column, up to now, as well as epibenthic species and species with an intermittent swimming behaviour (Armonies 1988a). By definition, only members of the latter 2 groups may actively enter the water column and only these species are studied. Therefore, the effects of physical factors on the emergence pattern are tested by counts of abundance of swimmers in the water column above constant amounts of sediment. Species that remained in the sediment during experiments are either entirely benthic or do not swim under the particular experimental conditions. However, it is an a posteriori decision if a certain species is entirely benthic or not. Therefore the numbers of non-swimmers contained in the sediment were not evaluated. It should be kept in mind, however, that the results only refer to the swimming species and not to some general activity of all species of a taxon.

\section{MATERIAL AND METHODS}

Sampling. For all experiments, samples were collected at a $30 \times 30 \mathrm{~m}$ plot of the Konigshafen wadden area near the Island of Sylt (North Sea). For a general description of the area see Reise (1985). The plot is sheltered and the sediment is mainly composed of medium sand (median diameter 315 um, sorting coefficient 1.5 ; cf. Schmidt 1968) with moderate amounts of detritus (loss on ignition $0.48 \%$ ). Experiments were performed in July, 1987. The seawater temperature was 15 to $16^{\circ} \mathrm{C}$ and air temperature varied between 10 and $20^{\circ} \mathrm{C}$. The sampled plot was positioned at mid-tide level ( $50 \%$ tidal emersion), and the average tidal range was about $1.8 \mathrm{~m}$ in this area and $0.9 \mathrm{~m}$ at the sampled plot.

Throughout all experiments, sediment samples were collected with a $2 \mathrm{~cm}^{2}$ plastic tube inserted to a depth of $2.5 \mathrm{~cm}$ (i.e. $5 \mathrm{~cm}^{3}$ volume sample ${ }^{-1}$ ) and transferred into glass jars for transport and subsequent experimenta- tion. The natural stratification of the sediment was retained as far as possible. The sampled sediment was about $50 \%$ by volume of the glass jars (inner diameter of jars $1.8 \mathrm{~cm}$, total height $4.5 \mathrm{~cm}$ ). To leave these jars, animals had to swim at least $2.5 \mathrm{~cm}$ above the sediment. Samples were collected at low tide, about $2 \mathrm{~h}$ before the sample site was again flooded by the sea. These $2 \mathrm{~h}$ were used for transport to the laboratory and sample preparation. Thus the experimental submersion started at about the same time as the sample site was flooded in the field.

Experimental design. Experiments were conducted according to the following standards. Each treatment in each experiment was simultaneously performed in 10 aquaria (10 replicates) using 1 glass jar per aquarium. The plastic aquaria $\left(10 \times 5 \times 10 \mathrm{~cm}=500 \mathrm{~cm}^{3}\right)$ were filled with $400 \mathrm{~cm}^{3}$ of filtered seawater and stored for at least $6 \mathrm{~h}$ to adapt to the experimental temperature of $15^{\circ} \mathrm{C}$ (= actual seawater temperature in July). Prior to submersion into these aquaria, the glass jars containing the sampled sediment were filled with seawater without agitating the sediment surface. The outer surface of the glass jars was cleaned from adhering sand grains and organisms if necessary. Submergence was initiated by carefully placing the jars into the aquaria with seawater. Since the jars had been previously filled with seawater to the rim, no losses of organisms by agitation of the sediment surface occurred. The standard period of experimental submergence was $6 \mathrm{~h}$. Afterwards, the glass jars with sediment were cautiously removed from the aquaria. Water in the aquaria was poured through a $63 \mu \mathrm{m}$ mesh sieve to retain emigrated meiobenthos. Water that remained in the glass jars with sediment was not evaluated.

Experimental treatments and null hypotheses. Experiment I: Emigration in a gradient of light exposure. Fifty sediment samples were collected and randomly distributed among 5 treatments with a variable light regime: (1) field conditions (daytime, direct sunlight); (2) light of $100 \mu \mathrm{E} \mathrm{m} \mathrm{m}^{-2} \mathrm{~s}^{-1}$; (3) light of $10 \mu \mathrm{E}$ $\mathrm{m}^{-2} \mathrm{~s}^{-1} ;$ (4) light of $1 \mu \mathrm{E} \mathrm{m} \mathrm{m}^{-2} \mathrm{~s}^{-1} ;$ (5) darkness $(<0.1 \mu \mathrm{E}$ $\mathrm{m}^{-2} \mathrm{~s}^{-1}$ ). Nos. (2) to (5) were simultaneously performed in a climate chamber. The differential light exposure was achieved by shading (transparent glass plate, glass with various layers of paper, dark grey plastic plates). At the same time, Treatment (1) was performed in front of the laboratory using direct sunlight. Initially it was cloudy $\left(1100 \mu \mathrm{Em}^{-2} \mathrm{~s}^{-1}\right)$ but it cleared up after $2 \mathrm{~h}$, and light increased to a maximum of $2250 \mu \mathrm{E} \mathrm{m} \mathrm{m}^{-2} \mathrm{~s}^{-1}$ (measured $3 \mathrm{~cm}$ above the water level in all cases). Despite continuous cooling by cold water flowing around each of the aquaria, temperature intermittently increased up to $18^{\circ} \mathrm{C}$. Experiment I tests the hypothesis $\mathrm{H}_{\mathrm{O}}$ (1). Meiofaunal emigration from the sediment is not affected by the degree of light exposure. 
Experiment II: Emigration in a gradient of temperature. Fifty sediment samples were randomly distributed among 5 treatments with variable temperature: (1) $5^{\circ} \mathrm{C}$, (2) $10^{\circ} \mathrm{C}$, (3) $15^{\circ} \mathrm{C}$ (ambient seawater temperature in the field), (4) $20^{\circ} \mathrm{C}$, and (5) $25^{\circ} \mathrm{C}$. The experiment was simultaneously performed in 5 climate chambers in the dark. Treatments (2) to (5) cover the range of temperatures measured in the field in July. In contrast, $5^{\circ} \mathrm{C}$ is not a realistic condition in July and was only included to test the effect of a (presumably harmless) extreme. Experiment II tests the hypothesis $\mathrm{H}_{0}(2)$ : Emigration is not affected by temperature in the range seasonally occurring in the field.

Experiment III: Oxygen deficiency. Seventy sediment samples were randomly distributed among 7 treatments. Treatment (1) was instantly submerged (control). The other samples were stored prior to submersion: (2), (3), and (4) were stored with continuous light $(100 \mu \mathrm{E}$ $\mathrm{m}^{-2} \mathrm{~s}^{-1}$ ) for 24,48 , and $72 \mathrm{~h}$, respectively. (5), (6), and (7) were stored for the same periods in the dark. The latter samples were only subjected to oxygen consuming processes and so became gradually anoxic while oxygen released from microphytobenthic photosynthesis prevented the former samples from anoxia. A small amount of filtered seawater $\left(1 \mathrm{~cm}^{3}\right)$ was added to the sediment samples before storage to avoid direct airsediment contact and so increase the oxygen changes arising. An extra set of 60 sediment samples was stored under the same conditions and the oxygen content of the overlying water measured with a probe after 24,48 , and $72 \mathrm{~h}$ respectively. In the dark-stored samples, oxygen decreased from $85 \%$ saturation (added seawater) to an average of $47 \%$ (31 to $56 \%$ ) with no significant change appearing among the $3 \mathrm{~d}$ of storage. The overlying water of the samples stored in continuous light rapidly increased in oxygen content and remained oversaturated over the $3 d$ (average $123 \%$ saturation, range 114 to $137 \%$ ). These measurements indicate that storage in the dark and light, respectively, really changed oxygen. After storage, the opportunity to emigrate was offered in the dark, irrespective of the former light regime. Experiment III tests the hypothesis $H_{0}$ (3): Emigration is not affected by the relative degree of oxygen availability (low versus high oxygen content)

Experiment IV: Changing salinity of the overlying water. Fifty sediment samples were randomly distributed among 5 treatments. The jars with sediment were cautiously filled with filtered seawater (30\% S). The aquaria were filled with (1) filtered seawater $(30 \%)=$ control, (2) water with $25 \%$, (3) water with $20 \%$ (dilution of seawater with tap water), (4) water with $35 \%$, and (5) water with $40 \%$ (mixing of seawater with an adequate amount of $120 \%$ solution produced from concentrated seawater). After submersion of the glass jars with sediment in the aquaria, the 35 and $40 \%$ water rapidly mixed with the seawater in the glass jars because of its higher specific density (visible streak formation). Mixing of the diluted seawater occurred only slowly by diffusion (no streak formation visible). Nevertheless, because of mixing the submersion period was restricted to $1 \mathrm{~h}$ (darkness). Experiment IV tests the hypothesis $\mathrm{H}_{0}(4)$ : Emigration is not affected by the salinity of overlying water.

Experiment V: Changing interstitial salinity. Sixty sediment samples were randomly distributed among 12 treatments (i.e. only 5 replicates per treatment in this experiment). Two h prior to submersion, the salinity of the interstitial water was manipulated by filling the glass jars with water of $0,5,10,15,20,25,30,35,40,45,50$, and $60 \% \mathrm{~S}$, respectively. Because of the interstitial water that was already present in the samples, the real salinity during experimentation differed from the salinity of the added water. These real salinities were refractrometrically measured after $2 \mathrm{~h}$ of adaptation. Then the glass jars with sediment were submerged in the aquaria with seawater $(30 \%=$ ambient salinity), and for $1 \mathrm{~h}$ animals were allowed to emigrate from the manipulated sediment in the dark (restricted period because of mixing). Experiment $V$ tests the hypothesis $\mathrm{H}_{0}$ (5): Emigration is not affected by the previous salinity of interstitial water.

Statistical evaluation. In the sediment as well as in the experimental water columns, the abundance of meiofaunal taxa differed significantly from a normal distribution (significant differences of the variance-to-meanratio from the appropriate reference of a chi-square table, $p=0.05$, Gage \& Geekie 1973). Therefore, the nonparametrical U-test (Wilcoxon et al., in Sachs 1984) is used throughout as a conservative measure. Trends were tested by Spearmans rank correlation coefficient (abbreviated by ' $r_{\mathrm{s}}$ ') and by run-tests (Sachs 1984). Significant results are indicated by ${ }^{\prime}(p<0.05), \cdots(p<$ $0.01)$, and $\cdots(p<0.001)$, respectively.

\section{RESULTS}

\section{Experiment I: Emigration in a gradient of light exposure}

Most Copepoda, Ostracoda, Plathelminthes and veliger-larvae (mainly Littorina littorea L.) emigrated in the dark and most rarely in full sunlight (Fig. 1). This trend is in all cases significant $\left(\mathrm{r}_{\mathrm{s}}, \cdots\right)$ and $\mathrm{H}_{0}$ (1) assuming no effect of light on the emergence pattern is rejected. Members of these taxa prefer the period of darkness for swimming into the water column. The polychaete abundance was not sufficient for a statistical evaluation. For Nematoda, Gastrotricha and Oligochaeta no significant emigration occurred at all.

The number of plathelminth species increases with 
Table 1. Plathelminth numbers per species (totals per 10 replicates) emerging from the sediment under variable light exposure. $>1000$ (daylight), $100,10,1$, and 0 (= darkness), expressed in $\mu E \mathrm{~m}^{-2} \mathrm{~s}^{-1} \mathrm{Pig}=$ pigmentation: + distinct, 0 weakly pigmented, - whitish

\begin{tabular}{|c|c|c|c|c|c|c|}
\hline \multirow[t]{2}{*}{ Species } & \multirow[b]{2}{*}{ Pig. } & \multicolumn{5}{|c|}{ Light exposure } \\
\hline & & $>1000$ & 100 & 10 & 1 & 0 \\
\hline Pogaina suecica Luther, 1948 & + & 1 & 2 & 5 & 12 & 6 \\
\hline Pogaina kinnei Ax, 1970 & + & 1 & & 1 & 1 & 1 \\
\hline Promesostoma marmoratum (M. Schultze 1851) & + & & 1 & & 3 & 1 \\
\hline Promesostoma caligulatum Ax, 1952 & + & & & 1 & 8 & 5 \\
\hline Macrostomum pusillum Ax, 1951 & 0 & & & & 3 & \\
\hline Provortex tubiferus Luther, 1948 & 0 & & & & 3 & \\
\hline Pseudaphanostoma sp. & - & & & & & 4 \\
\hline Archilopsis arenaria n. n. & - & & & & & 1 \\
\hline Promesostoma meixneri Ax, 1951 & - & & & & & 4 \\
\hline Cheliplana remanei (Meixner 1928) & - & & & & & 5 \\
\hline Acrorhynchides robustus (Karling 1931) & - & & & & & 1 \\
\hline Gyratrix hermaphroditus Ehrenberg, 1831 & - & & & & & 1 \\
\hline No. of individuals & & 2 & 3 & 7 & 30 & 29 \\
\hline No. of species & & 2 & 2 & 3 & 6 & 10 \\
\hline
\end{tabular}

decreasing light exposure $\left(I_{S i} \cdots\right)$. Four species entered the water column at light of $10 \mu \mathrm{E} \mathrm{m}^{-2} \mathrm{~s}^{-1}$ or more. They are all pigmented: Pogaina species are yellowish brown from symbiotic diatoms and the Promesostoma species bear a brown (net-like or striped) dorsal pigmentation. Macrostomum pusillum and Provortex tubiferus that entered the water column at $1 \mu \mathrm{E} \mathrm{m} \mathrm{m}^{-2} \mathrm{~s}^{-1}$ may also be weakly pigmented by partly digested diatom food. Finally, the 6 species that entered the
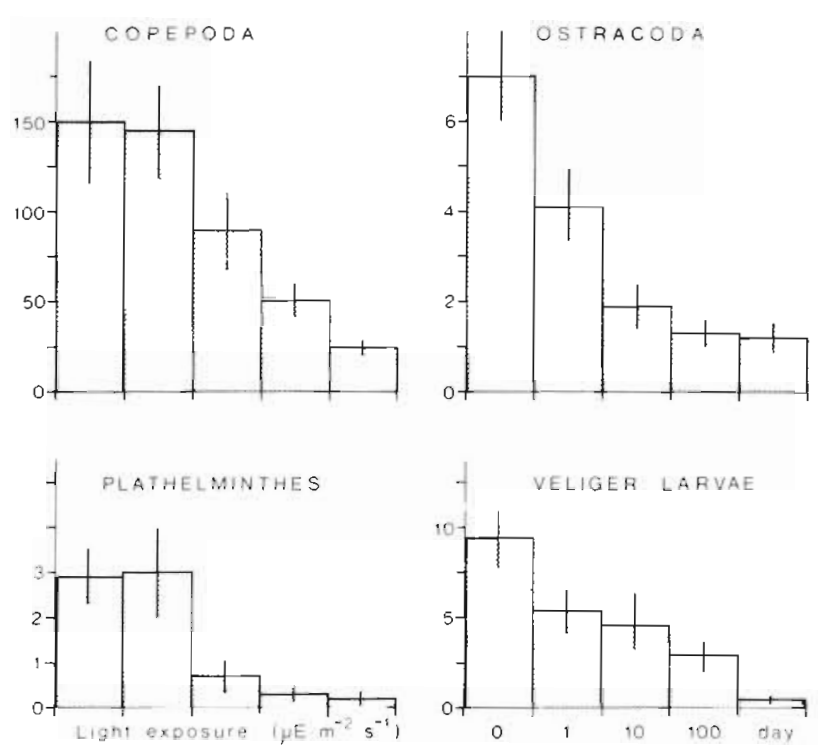

Fig. 1. Numbers of meiofauna individuals emigrating from the sediment in a gradient of light exposure; $0,1,10,100$, and daylight (day) $>1000$, expressed in $\mu \mathrm{E} \mathrm{m}^{-2} \mathrm{~s}^{-1}$ Vertical: mean abundance per sample unit $\left(2 \mathrm{~cm}^{2}\right.$ sediment surface area) $\pm \mathrm{SE}$ (vertical bars) water column in the dark are all whitish without distinct pigmentation (Table 1).

\section{Experiment II: Emigration in a gradient of temperature}

Copepoda, Ostracoda, Plathelminthes and veligerlarvae (mainly Littorina littorea) emigrated in sufficient
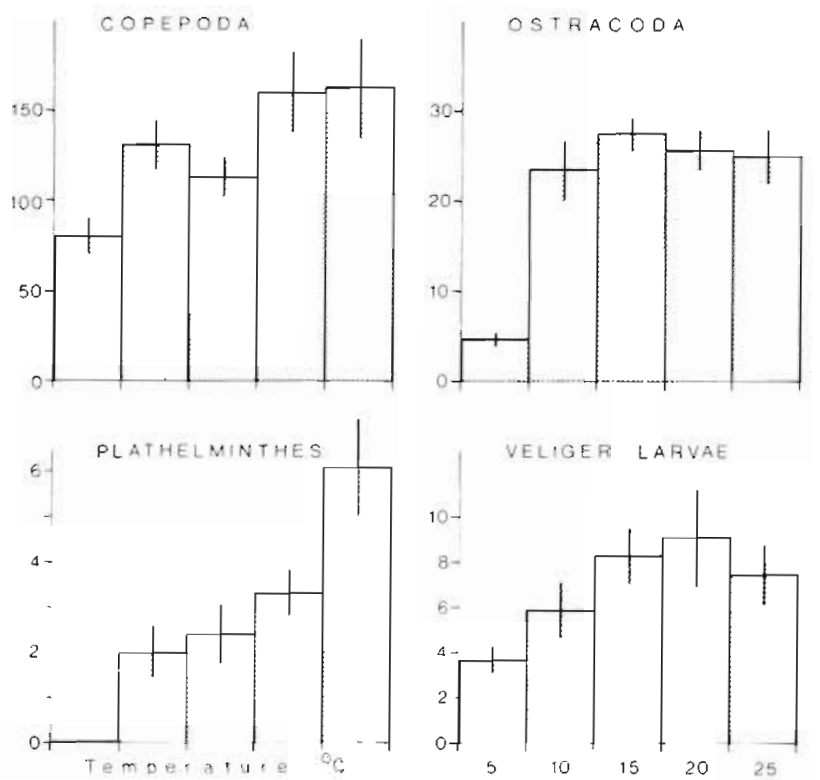

Fig. 2. Numbers of meiofauna individuals emigrating from submerged sediment into water of different temperatures Vertical: mean abundance per sample unit of $2 \mathrm{~cm}^{2}$ sediment surface $\pm \mathrm{SE}$ 
Table 2. Plathelminth numbers per species (totals per 10 replicates) emerging from the sediment under variable temperature $\left({ }^{\circ} \mathrm{C}\right.$ )

- indicates positive correlation between numbers and increasing temperature (Spearmans rank correlation coefficient $p<0.05$ )

\begin{tabular}{|c|c|c|c|c|c|}
\hline \multirow[t]{2}{*}{ Species } & \multicolumn{5}{|c|}{ Temperature $\left({ }^{\circ} \mathrm{C}\right)$} \\
\hline & 5 & 10 & 15 & 20 & 25 \\
\hline Pogaina suecica Luther, 1948 & - & 13 & 6 & 6 & 23 \\
\hline Cheliplana remanei (Meixner 1928) & - & 2 & 2 & 2 & $4^{\circ}$ \\
\hline Archilopsis arenaria n. $\mathrm{n}$. & - & 1 & - & 2 & 1 \\
\hline Provortex tubiferus Luther, 1948 & - & 1 & 1 & - & 2 \\
\hline Trigonostomidae indet. & - & 1 & - & - & - \\
\hline Promesostoma karlingi Ehlers, 1974 & - & 1 & - & - & - \\
\hline Promesostoma marmoratum (M. Schultze 1851) & - & 1 & 1 & 2 & 1 \\
\hline Promesostoma meixneri Ax, 1951 & - & - & 4 & 7 & $20^{\circ}$ \\
\hline Promesostoma caligulatum Ax, 1952 & - & - & 8 & 8 & 6 \\
\hline Pseudaphanostoma psammophilum Dörjes, 1968 & - & - & 1 & 4 & 2 \\
\hline Gyratrix hermaphroditus Ehrenberg, 1831 & - & - & 1 & - & 1 \\
\hline Macrostomum pusillum $\mathrm{Ax}, 1951$ & - & - & - & 1 & 1 \\
\hline Provortex psammophilus Ax, 1951 & - & - & - & 1 & - \\
\hline No. of individuals & 0 & 20 & 24 & 33 & $61^{\circ}$ \\
\hline No. of species & 0 & 7 & 8 & 9 & $10^{\circ}$ \\
\hline
\end{tabular}

numbers for a statistical evaluation. In all cases emigration rates are significantly smallest at $5^{\circ} \mathrm{C}$ (U-test, "). Spearmans rank correlation coefficient indicates positive relationships between emigration activity and temperature in Copepoda $\left(\mathrm{r}_{\mathrm{s}}=+0.9^{\circ}\right)$, Plathelminthes $\left(\mathrm{r}_{\mathrm{s}}=+1.0^{\circ}\right)$ and veliger-larvae $\left(\mathrm{r}_{\mathrm{s}}=+0.9^{*}\right)$. In Ostracoda the correlation is only significant when a positive trend is assumed a priori (one sided test, $r_{\mathrm{s}}=$ $0.867^{\circ}$, Fig. 2).

In Plathelminthes, the numbers of Cheliplana remanei and Promesostoma meixneri are significantly correlated with temperature, as is the total number of emerging species $\left(r_{\mathrm{s},} \cdot\right)$. The increase in species numbers is presumably only an effect of increased plathelminth abundance in the water column (Table 2). Thus, temperature correlates positively with the emigrative activity of Copepoda, Ostracoda, Plathelminthes and veliger-larvae of Littorina littorea and $\mathrm{H}_{0}(2)$ is rejected.

\section{Experiment III: Oxygen deficiency}

In the dark-stored samples the lowermost portion of the sediment gradually turned black indicating oxygen depletion. Copepoda and Plathelminthes both show a significant response towards this change of oxygen, whereas Ostracoda did not show any significant difference between the treatments. Other taxa were not sufficiently abundant for a statistical evaluation. Sorting of the sediment of 2 randomly chosen glass jars per treatment gave no sign of the experimental procedure being harmful to the tested taxa (no dead or unusually behaving animals).

Copepod abundances did not differ between the control and the dark stored samples, and there is no significant difference among the samples stored in the dark (Fig. 3). However, significantly more copepodites emerged from the samples stored with light than from both control (") and dark-stored samples (", U-test; nauplii are not included in the copepod numbers).

Significantly more Plathelminthes emigrated from the samples stored in the dark when compared to both control samples (U-test ${ }^{*}$ ) and samples stored with light (U-test $\cdots$, Fig. 3). The storage period had no significant effect on the numbers of emerging species.

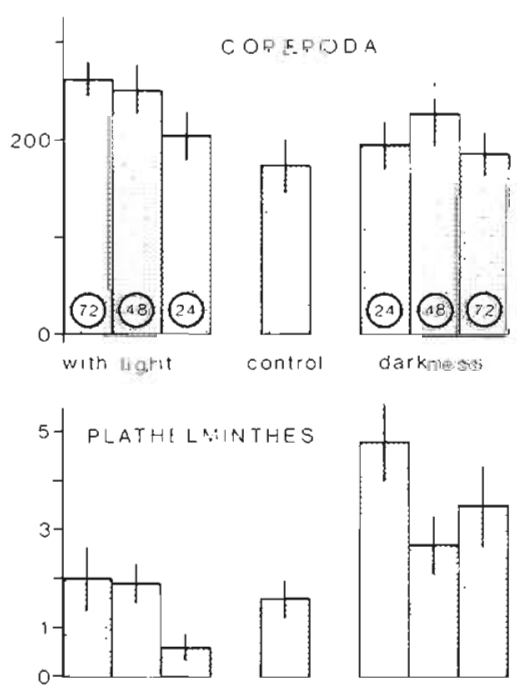

Fig. 3. Numbers of meiofauna individuals emigrating from submerged sediment without storage (control) and after 24. 48 , and $72 \mathrm{~h}$ of storage in dark or light, respectively. Mean abundance per sample unit of $2 \mathrm{~cm}^{2}$ sediment surface area $\pm \mathrm{SE}$ 
Table 3. Plathelminth numbers per species emerging per $10 \mathrm{~cm}^{2}$ of sediment after storage in dark and light, respecively. Control $=$ no storage $(n=10)$. Since the period of storage did not signuficantly change the numbers of emerging individuals, numbers emerging after 24,48 , and $72 \mathrm{~h}$ of storage in light or in dark have been averaged $(n=30)$

\begin{tabular}{|c|c|c|c|}
\hline Species & Control & $\begin{array}{c}\text { Storage } \\
\text { in } \\
\text { light }\end{array}$ & $\begin{array}{c}\text { Storage } \\
\text { in } \\
\text { dark }\end{array}$ \\
\hline Pogaina suecica & 2.0 & 1.2 & 5.3 \\
\hline Pogaina kinnei & 1.5 & 1.3 & 3.2 \\
\hline Promesostoma caligulatum & 4.5 & 4.5 & 6.0 \\
\hline Provortex tubiferus & 0 & 0.2 & 0.3 \\
\hline $\begin{array}{l}\text { Pseudaphanostoma } \\
\text { psammophilum }\end{array}$ & 0 & 0.3 & 0.7 \\
\hline $\begin{array}{l}\text { Cheliplanilla caudata } \\
\text { Meixner, } 1938\end{array}$ & 0 & 0 & 0.5 \\
\hline Cheliplana remanei & 0 & 0 & 0.2 \\
\hline Promesostoma meixneri & 0 & 0 & 1.3 \\
\hline Macrostomum pusillum & 0 & 0 & 0.3 \\
\hline Promesostoma marmoratum & 0 & 0 & 0.3 \\
\hline Typhloplanoida indet. & 0 & 0 & 0.2 \\
\hline Total individuals & 8.0 & 7.5 & 18.3 \\
\hline No. of species & 3 & 5 & 11 \\
\hline
\end{tabular}

Pogaina suecica, P. kinnei, and Promesostoma caligulatum emigrated from all treatments (though at different rates) while other species only emerged after storage in the dark (Table 3). Plathelminthes might therefore be divided into obligatory and facultative swimmers, and oxygen deficiency is a possible stimulus causing the latter group to enter the water column. Consequently, the number of emerging plathelminth species is higher after storage in the dark (Table 3. Fig. 3).

From Experiment III it is concluded that the relatively lower oxygen content of the dark stored samples when compared to the samples stored with light causes no increase in the number of emerging adult copepods, but continuous light correlates with a higher rate of emerging copepodites. Reduced oxygen causes significantly more Plathelminthes (species as well as individuals) to emigrate from the sediment and $H_{0}(3)$ is rejected. Ostracoda showed no differences between treatments, and $\mathrm{H}_{0}(3)$ is therefore maintained for this taxon.

\section{Experiment IV: Changing salinity of the overlying water}

Copepoda, Ostracoda and Plathelminthes show significant differences in their emigration rates into water of varying salinity. Copepod emigration does not differ among $30 \%$ (control), 25 and $35 \% \mathrm{~S}$ (Fig. 4). This is the range of salinity that may easily occur at the sampled intertidal flat by evaporation and precipitation. Emigration rates are significantly smaller outside this range (", U-test, Fig. 4). Ostracoda behave very similar, but only the decrease in activity at $40 \% \mathrm{~S}$ is significant. The highest numbers of Plathelminthes emigrated into diluted seawater whereas few individuals entered the high salinity water. In this taxon, emergence correlates negatively with the salinity of overlying water $\left(\mathrm{r}_{\mathrm{s}}=\right.$ -0.925 ). Sorting of the sediment of 2 randomly chosen glass jars per salinity treatment after submergence gave no sign of a harmful effect of salinity to the studied taxa during the $1 \mathrm{~h}$ of submersion (no dead or unusually behaving animals).

\section{Experiment V: Changing interstitial salinity}

Variation in the salinity of interstitial water did not cause any significant differences in the activity pattern of Ostracoda and veliger-larvae (mainly Littorina littorea). This might be caused by relatively low abundance of the latter group, but not in the case of Ostracoda.

The highest numbers of Plathelminthes emigrated from salinities of 30 to $43 \% \mathrm{~S}$. (Because of the interstitial water that was already present in the samples, the experimental salinities differ from the salinity of the added water - for evaluation, I used the real salinities of interstitial water measured after the $2 \mathrm{~h}$ of adaptation.) The numbers of plathelminths that emigrated
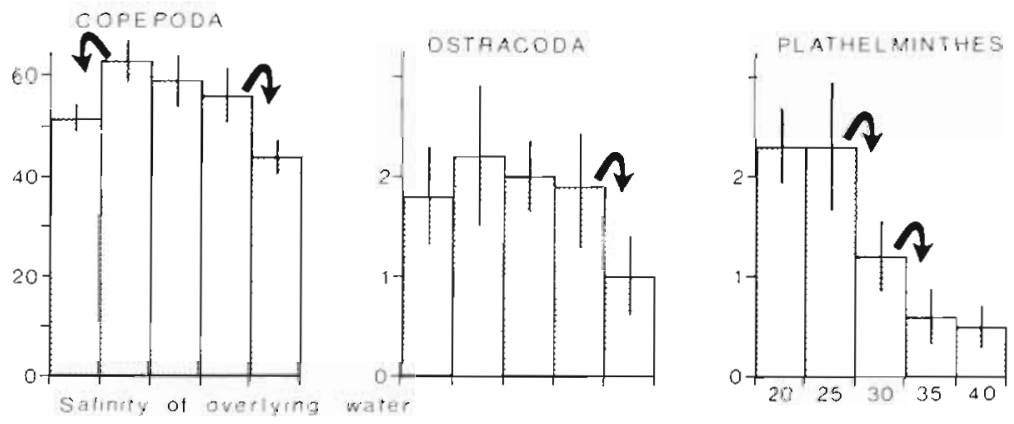

Fig. 4. Numbers of meiofauna individuals (mean per $\mathrm{cm}^{2}$ of sediment surface area $\pm \mathrm{SE}$ ) emigrating from untreated sediment samples into water of varying salinity. Arrows: significant abundance difference between consecutive steps of salinity (U-test, $p<0.05$ ) 
from the sediment is not random over the gradient of interstitial salinities (run-test, *). Significantly more individuals emigrated from salinities higher than $30 \%$ than from diluted seawater (U-test $;$ Fig. 5). Some species such as Promesostoma meixneri only emigrated from an interstitial salinity of $30 \%$ and more. The dominant emigrators Pogaina suecica and Promesostoma caligulatum did not show a significant difference in the salinity gradient, however, highest numbers per sample emigrated also from increased salinities.

Copepoda show the strongest reaction towards the experimentelly changed interstitial salinity (Fig. 5). The order of abundances is not random but high and low values are clumped (", run-test). Starting at $6 \% \mathrm{~S}$, the number of emigrated specimens monotonically increases up to $35 \% \mathrm{~S}\left(\mathrm{r}_{\mathrm{s}}=+1.0 \cdots\right)$. Abundances between 26 and $47 \%$ do not significantly differ among each other (U-test, $p>0.05$ ) but abundance is decreased at $59 \%$ ( $\cdots$, U-test).

For Plathelminthes and Copepoda, $\mathrm{H}_{0}$ (5) no influence of interstitial salinity on emigration rates is rejected. These taxa show significantly strongest emigration from interstitial salinities $>30 \%$ S (Plathelminthes) and between 26 and $47 \%$ (Copepoda). Sorting of the sediment of 1 randomly chosen glass jar per treatment after submersion gave no sign of a damage of the tested specimens during $1 \mathrm{~h}$ of submersion.

\section{DISCUSSION}

\section{Behavioural versus physically forced emergence}

Infauna that leave the sediment are in danger of being preyed upon by planktonic and pelagic predators. Since at least some of these are visually feeding, a higher nocturnal than diurnal swimming activity should reduce the risk of being preyed upon and is therefore regarded as a means of predator avoidance. In the present study, all taxa emerging in significant abundance were more active in the dark and harpacticoids of tropical seagrass meadows show the same diurnal pattern (Walters \& Bell 1986). The slight increase in emigration activity with increasing temperature is also an effect generally observed, presumably reflecting the increase in metabolic intensity with increasing temperature. However, the paralleling decrease in oxygen availability may also contribute to this pattern. In the tested gradient of light exposure (Expt I) samples stored in direct sunlight became intermittently warmer $\left(18^{\circ} \mathrm{C}\right)$ than other treatments $\left(15^{\circ} \mathrm{C}\right)$. This higher temperature should have increased emigration (Expt II). Nevertheless, the number of emigrators followed the general tendency with the highest emergence in the dark and the least in full sunlight. It

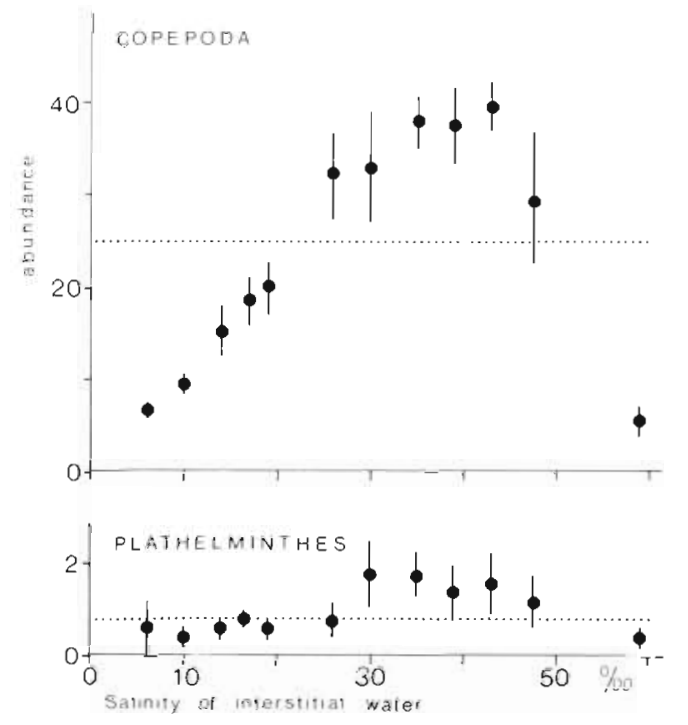

Fig. 5. Numbers of meiofauna individuals (mean per $2 \mathrm{~cm}^{2}$ of sediment surface area $\pm \mathrm{SE}$ ) emerging from sediment with a manipulated interstitial salinity into seawater Dotted lines: overall means

seems that light exerts a stronger influence on the emigrative activity than does temperature in the tested range.

Oxygen availability affects the number of Plathelminthes and copepodites leaving the sediment (Fig. 3, Table 3). Most Copepoda, Ostracoda and Plathelminthes depend on oxygen, and there are few, if any, species that can permanently survive under anoxic conditions. In the present study, the sediment samples enclose the uppermost oxygenated sediment layer plus the oxic/anoxic transition zone (roughly estimated according to sediment colour). The increased emigration rates correlating with decreased oxygen availability are therefore interpreted as an escape behaviour. However, some plathelminth species, Copepoda and Ostracoda also leave the sediment when oxygen availability at the sediment surface is relatively high by continuous illumination, and they also leave if no experimental change occurred. Escape from low oxygen conditions is therefore not a general explanation for emigrative behaviour of infauna.

Differential numbers of Copepoda, Ostracoda and Plathelminthes emigrated into water of varying salinity. Provided swimming into the water column is part of the normal way of life in these species, and not only escape from some unfavourable factors prevailing in the sediment, high rates of emergence should be interpreted as indicators of benign conditions. Then, Copepoda and Ostracoda favour salinities between 25 and $35 \% \mathrm{~S}$ (which is the range regularly occurring in the field) but reject to enter 20 and $40 \%$ water. Plathelminthes, however, seem to favour a lower salinity than 
does naturally occur in the field, and they reject water of a higher salinity,

Experimentally changing interstitial salinity caused significantly more Plathelminthes to emigrate from high salinity sediment than from low salinity sediment. This higher swimming activity is mainly due to some additional species entering the water column such as Promesostoma meixneri, which did not leave the lowsalinity sediment. In the tidal gradient, highest abundance of this species is found in the upper intertidal and lower supratidal belt where salinity is often reduced (Hellwig 1987). Presumably P. meixneri favors a salinity in the polyhaline range (18 to $30 \%$ S). When salinity was experimentally increased beyond that level, $P$. meixneri started swimming into the seawater. Other species such as Pogaina suecica and Promesostoma caligulatum did not show significant differences among their numbers emigrating from differential interstitial salinities. These species occur in the intertidal and supratidal but highest abundance is found in detritus rich salt marsh creeks (Hellwig 1987, HellwigArmonies \& Armonies 1987). In salt marsh creeks, salinity may vary considerably, and these species are presumably more euryhaline. Plathelminth species that show highest abundance in the sublittoral did not occur in this study, neither swimming nor resting in the sediment.

\section{Obligatory versus facultative swimming}

In the studied intertidal flat, the assemblage of Plathelminthes (Tables 1, 2, 3) can be divided into obligatory and facultative swimmers (i.e. accidental and non-accidental migration, respectively, see Baker 1978). Emergence from the sediment seems to belong to the normal way of life in obligatory swimmers (nonaccidental migrators), and experimental change of physical factors causes only relatively small changes in their swimming behaviour. Contrary, facultative swimmers (accidental migrators) only leave the sediment to escape from unfavourable conditions (which may be physical factors such as the ones tested, as well as biotic factors). Species with an intermittent behaviour connect both groups. In addition, planktonic species such as calanoid copepods occurred in many sediment samples of this intertidal flat. Swimming benthos and planktonic species occasionally resting at the sediment surface ecologically connect plankton and benthos. These groups are not distinctly separated in the Wadden Sea.

In a previous study of meiobenthic swimming behavior, most of the plathelminths among the active swimmers proved to be diatom-feeders, predators on copepods or unspecific predators (Armonies 1988a).
This group meets with the above obligatory swimmers. Possibly, they find additional (or their only?) prey in the water column, as has been demonstrated for some copepod species (Decho 1986). Bacteria-feeders and predators on non-swimming (or facultative swimming) benthos are typically facultative swimmers (Armonies 1988a). If some diatom-feeders emerge into the water column for feeding, correlations between their numbers and diatom abundance in the sediment cannot be expected. This is the situation found by Montagna et al. (1983).

\section{Emergence affected by hydrodynamical factors}

The laboratory experiments referred to above suggest rather high mobility of small benthos via the water column. Light, temperature, oxygen availability and salinity all influence the emergence activity. Swimming is also affected by currents (Bell \& Sherman 1980 , Hagerman \& Rieger 1981, Fleeger et al. 1984, Palmer 1984) and some taxa show even higher activity in the presence of currents (Armonies 1988b). Active swimming is therefore not an artifact of the experimental noflow conditions, but it occurs despite the exclusion of flow. With increasing current speed, additional taxa such as Nematoda are found in the water column (Palmer 1986, Armonies 1988b) indicating that both active emergence and passive drift contribute to the occurrence of benthos in the water column. Downward migrations in the sediment column may decrease the susceptibility of benthic species to passive erosion (Palmer \& Gust 1985, Palmer \& Molloy 1986). Some species do not move to deeper sediment layers as flow starts (Boaden 1968, Boaden \& Platt 1971, Palmer \& Molloy 1986) but they keep their position or even move upward. Presumably, these species are the potential swimmers. However, since active swimming is decreased in stronger flow (Armonies 1988b) the direction of vertical migrations may be flow dependent. The presence of structure (Spartina culms or mimics) is another factor affecting active emergence and passive drift of meiofauna (Palmer 1986) but in a nonpredictable manner.

\section{Consequences of meiofaunal emergence}

The high mobility of some meiobenthic taxa suggests the need for some changes in the traditional view of intertidal meiobenthos. (1) Because of specific differences in emigrative activity (at least in Plathelminthes, this study and Armonies 1988a, b; and in harpacticoids, Bell et al. 1987. Walters 1988), plankton and benthos are not distinctly separated in shallow waters 
Abundance and population structure of swimmers may show short-term temporal variations, as has already been demonstrated for harpacticoids (Kern \& Bell 1984). (3) Similarly, specific differences in the swimming activity may cause short-term changes of the faunal composition. (4) Only rough small-scale correlations can be expected between the abundance of active swimmers and sediment properties such as granulometric composition. Instead, there will always be some specimens that failed to find an optimal benthic habitat after an excursion into the water column. (5) Some benthic specimens may exploit food resources in the water column. In the sediment their abundance cannot be expected to correlate with the abundance of potential food items. (6) While swimming in the water column, benthos may be subject to predation by planktonic and pelagic predators. Some juvenile fish of the Wadden Sea are known to prey on benthic harpacticoids (e.g. Pihl 1985, Gee 1987, Zander \& Hagemann 1987). Since this knowledge usually derives from examination of the stomach contents, it is not known if the fish caught their prey in the water column or by burrowing at the sediment surface. The same applies to invertebrate predators such as shrimp (e.g. Pihl \& Rosenberg 1984).

In previous studies on meiobenthic ecology, harpacticoids and plathelminths were treated as any other benthic taxon. However, in retrospective it seems questionable if species which perform routine migrations into the water column should be attached to 'benthos'. Omitting these species will certainly result in a somewhat changed view of the ecology of the remaining communities of 'holobenthic' meiofauna.

Acknowledgements. This study was supported by a grant from the 'Biologische Anstalt Helgoland'. Professor Dr Karsten Reise and 3 unknown reviewers improved the manuscript by offering critical comments.

\section{LITERATURE CITED}

Alldredge, A. L., King, J. M. (1980). Effects of moonlight on the vertical migration patterns of demersal zooplankton. J. exp. mar. Biol. Ecol. 44: 133-156

Armonies, W. (1987). Freilebende Plathelminthen in supralitoralen Salzwiesen der Nordsee: Ökologie einer borealen Brackwasser-Lebensgemeinschaft. Microfauna marina 3: 81-156

Armonies, W. (1988a). Active emergence of meiofauna from intertidal sediment. Mar. Ecol. Prog. Ser. 43: 151-159

Armonies, W. (1988b). Hydrodynamic factors affecting behaviour of intertidal meiobenthos. Ophelia 28: 183-193

Armonies, W., Hellwig, M. (1986). Quantitative extraction of living meiofauna from marine and brackish muddy sediments. Mar. Ecol. Prog. Ser. 29: 37-43

Baker, R. R. (1978). The evolutionary ecology of animal migration. Hodder \& Stoughton, London

Bell, S. S., Sherman, K. M. (1980). A field investigation of meiofaunal dispersal: tidal resuspension and implications Mar. Ecol. Prog. Ser. 3: 245-249

Bell, S. S., Walters, K., Hall, M. O. \{1987\}. Habitat utilization by harpacticoid copepods: a morphometric approach. Mar. Ecol. Prog. Ser 35: 59-64

Boaden, P. J. S. (1968). Water movement - a dominant factor in interstitial ecology. Sarsia 34: 125-136

Boaden, P. J. S., Platt, H. M. (1971). Daily migration patterns in an intertidal meiobenthic community. Thalassia jugosl. 7 : $1-12$

Decho, A. W. (1986). Water-cover influences on diatom ingestion rates by meiobenthic copepods. Mar. Ecol. Prog. Ser 33: $139-146$

Fenchel, T., Jansson, B.-O., Thun, W. von (1967). Vertical and horizontal distribution of the metazoan microfauna and of some physical factors in a sandy beach in the northern part of the Øresund. Ophelia 4: 227-243

Fleeger, J. W., Chandler, G. T., Fitzhugh, G. R., Phillips, F. E (1984). Effects of tidal currents on meiofauna densities in vegetated salt marsh sediments. Mar. Ecol. Prog. Ser. 19 49-53

Gage, J., Geekie, A. D. (1973). Community structure of the benthos in Scottish sea-lochs. II. Spatial pattern. Mar. Biol. 19: 41-53

Gee, J. M. (1987). Impact of epibenthic predation on estuarine intertidal harpacticoid copepod populations. Mar. Biol. 96 $497-510$

Hagermann, G. M., Rieger, R. M. (1981). Dispersal of benthic meiofauna by wave and current action in Bague Sound, North Carolina, USA. P.S.Z.N.I.: Mar Ecol. 2: 245-270

Hellwig, M. (1987). Ökologie freilebender Plathelminthen im Grenzraum Watt - Salzwiese lenitischer Gezeitenküsten. Microfauna marina 3: 157-248

Hellwig-Armonies, M., Armonies, W. (1987). Meiobenthic gradients with special reference to Plathelminthes and Polychaeta in an estuarine salt marsh creek - a small scale model for boreal tidal coasts? Helgoländer Meresunters. 41: 201-216

Jansson, B.-O. (1967a). The availability of oxygen for the interstitial fauna of sandy beaches. J. exp. mar Biol. Ecol. 1: $123-143$

Jansson, B.-O. (1967b). Diurnal and annual variations of temperature and salinity of interstitial water in sandy beaches. Ophelia 4: 173-201

Kern, J. C., Bell, S. S. (1984). Short-term temporal variation in population structure of two harpacticoid copepods Zausodes arenicolus and Paradactylopodia brevicornis. Mar. Biol. 84: 53-63

Montagna, P. A., Coull, B. C., Herring, T. L., Dudley, B. W. (1983). The relationship between abundances of meiofauna and their suspected microbial food (diatoms and bacteria). Estuar. coast. Shelf Sci. 17: 381-394

Palmer, M. A. (1984). Invertebrate drift: behavioral experiments with intertidal meiobenthos. J. mar. Behav. Physiol 10: 235-253

Palmer, M. A. (1986). Hydrodynamics and structure: interactive effects on meiofauna dispersal. J. exp. mar. Biol. Ecol. 104: 53-68

Palmer, M. A., Gust, G. (1985). Dispersal of meiofauna in a turbulent tidal creek. J. mar. Res. 43: 179-210

Palmer, M. A., Molloy, R. M. (1986). Water flow and the vertical distribution of meiofauna: a flume experiment. Estuaries 9: 225-228

Pihl, L. (1985). Food selection and consumption of mobile epibenthic fauna in shallow marine areas. Mar Ecol. Prog Ser. 22: 169-179

Pihl, L., Rosenberg, R. (1984). Food selection and consumption 
of the shrimp Crangon crangon in some shallow marine areas in western Sweden. Mar. Ecol. Prog. Ser. 15: $159-168$

Reise, K. (1985). Tidal flat ecology. Springer, Berlin

Revsbech, N. P., Sørensen, J., Blackburn, T. H., Lomholt, J. P.

(1980). Distribution of oxygen in marine sediments measured with microelectrodes. Limnol. Oceanogr. 25: 403-411 Sachs, L. (1984). Angewandte Statistik. Springer, Berlin

Schmidt, P. (1968). Die quantitative Verteilung und Populationsdynamik des Mesopsammons am GezeitenSandstrand der Nordseeinsel Sylt. I. Faktorengefüge und biologische Gliederung des Lebensraumes. Int. Revue ges. Hydrobiol. 53: 723-779

Walters, K. (1988). Diel vertical migration of sediment-associated meiofauna in subtropical sand and seagrass habitats. J. exp. mar. Biol. Ecol. 117: 169-186

Walters, K., Bell, S. S. (1986). Diel patterns of active vertical migration in seagrass meiofauna. Mar. Ecol. Prog. Ser. 34: 95-103

Zander, C. D., Hagemann, T (1987). Predation impact and ecological efficiency of Pomatoschistus spp. (Gobiidae, Pisces) from a clay/sand ecotone of the western Baltic Sea. Zool. Anz 218: 33-48

This article was submitted to the editor; it was accepted for printing on September 15, 1988 